\section{$\varphi$ \\ Institut Pasteur de Montevideo \\ YOUNG GROUP LEADER POSITION} IN BASIC BIOMEDICAL RESEARCH

The Institut Pasteur de Montevideo is an international scientific institution recently founded in Montevideo (Uruguay), whose mission is to contribute to the development of biomedical research in the MERCOSUR region, by strengthening research and education in post-genomics biomedicine and biotechnology.

The IP Montevideo will bring together in 2010 , one research group lead by a young researcher, supported by outstanding core facilities in genomics, protein biochemistry, proteomics, structural biology, cellular and proteomics, structural molecular biology and bioinformatics. Applications focused on post-genomic medicine, fully exploiting these facilities and having scientific excellence will be privileged.

The IP Montevideo invites young group leaders to apply for a 5-year research award (US\$ 100,000.00 p/year)

Deadline for applications: December 20th 2009

Complete details of this position at: www.pasteur.edu.uy

enquiries: llamados@pasteur.edu.uy Supported by:

$$
\text { = URUGUAYINNOVA: }
$$

\section{Post-doctoral and Young Investigator Awards in São Paulo, Brazil}

Established in 1962, the São Paulo Research Foundation, FAPESP, is one of the main research funding agencies in Brazil. With a US\$ 400 million budget for 2009, it supports 11,000 scholarships and 8,000 research awards. In addition to supporting all fields of science, FAPESP has special research programs in biodiversity, bioenergy, global climate change, neuroscience, information technology and public policy. The State of São Paulo, in Brazil, is a dynamic, fast growing center with a population of 40 million people, producing $40 \%$ of Brazil's industrial output. Higher education and research institutions in São Paulo awarded 4,900 PhD degrees last year.

Post-doctoral positions: FAPESP invites talented researchers with a recent PhD degree and a successful research track record to apply for postdoctoral fellowships. Currently 16 positions are open (http://www.fapesp.br/opp) associated with projects with secured funding in molecular and cell biology, immunology, plant genetics, biochemistry and education Postdoctoral fellows benefit from a highly collaborative, stimulating research environment and access to world-class university research and teaching. Appointments are for one year, renewable for up to three or four years, according to each opening. The stipend is equivalent to (estimated using the official exchange rate in October, 2009) US\$32,000/year plus roundtrip air tickets for researcher and family, support for relocation expenses, and research contingency funds of US\$4,700/year. Awards are competitive, with selection emphasis placed on research promise. For additional information: pd@fapesp.br.

Young Investigator Awards: FAPESP's Young Investigator Awards envisage creating new research groups led by highly promising early-career scientists in any field of knowledge (http://www.fapesp.br/yia). Selected candidates will receive a fellowship and sizable research funds for full development of their research project (up to 48 months). Candidates are encouraged to develop their research interests in association with faculty in higher education and research institutions in São Paulo. Highlighted research areas are bioenergy, neurosciences, climate change, cancer, materials science, optics and photonics, urban studies and violence, but proposals in other fields will be considered. Selection is through peer review.

For guidance and further information: yi@fapesp.br. Additional information: (http://www.fapesp.br/en)

NW186483R

\section{Department of Biochemistry Universidade de São Paulo, Brazil}

The Department of Biochemistry at Universidade de São Paulo (USP) will be expanding its faculty in the next two years. We seek individuals that are enthusiastic to develop competitive, independent research programs in any area of Biochemistry and/or Molecular Biology. Candidates should hold PhD or equivalent titles and possess significant postdoctoral experience.

Biochemistry at USP (http://www2.iq.usp.br/bioquimica/) is one of the top biological research departments in Brazil, with internationally recognized experts in the fields of molecular neuroscience, cancer, host-pathogen interactions, plant genomics, protein structure and redox processes. Our goal is to create an ever more international scientific environment by attracting top talents locally and abroad. We value undergraduate teaching and the mentoring of graduate students.

Brazil is going through an unprecedented expansion of its research system backed by a firm governmental commitment to the development of local science and technology. Support for research comes from a variety of national sources including FAPESP, the funding agency from the State of São Paulo (http://www.fapesp.br/). Funding levels and research infrastructure is at par with that in average US and European universities and includes state of the art confocal microscopy, mass spectrometry and next-generation sequencing facilities. The Department also hosts a motivated and talented student body that includes 130 graduate students, over 30 postdoctoral fellows, and many undergraduate research students. São Paulo, Brazil's largest city, is a diverse and cosmopolitan metropolis, with world class infrastructure and services and a vibrant arts and entertainment scene.

There are two types of positions currently available:

Tenure-track positions: Applicants for these positions must have their PhD diplomas recognized by the University of São Paulo. Portuguese proficiency is a plus but is not required.

Non tenure-track positions: 4 year positions to be funded through FAPESP grants. These grants include salary and funds for lab expenditures. Temporary positions do not require knowledge of Portuguese or recognition of foreign diplomas.

Further inquires about both types of positions can be made by contacting depqbq@iq.usp.br

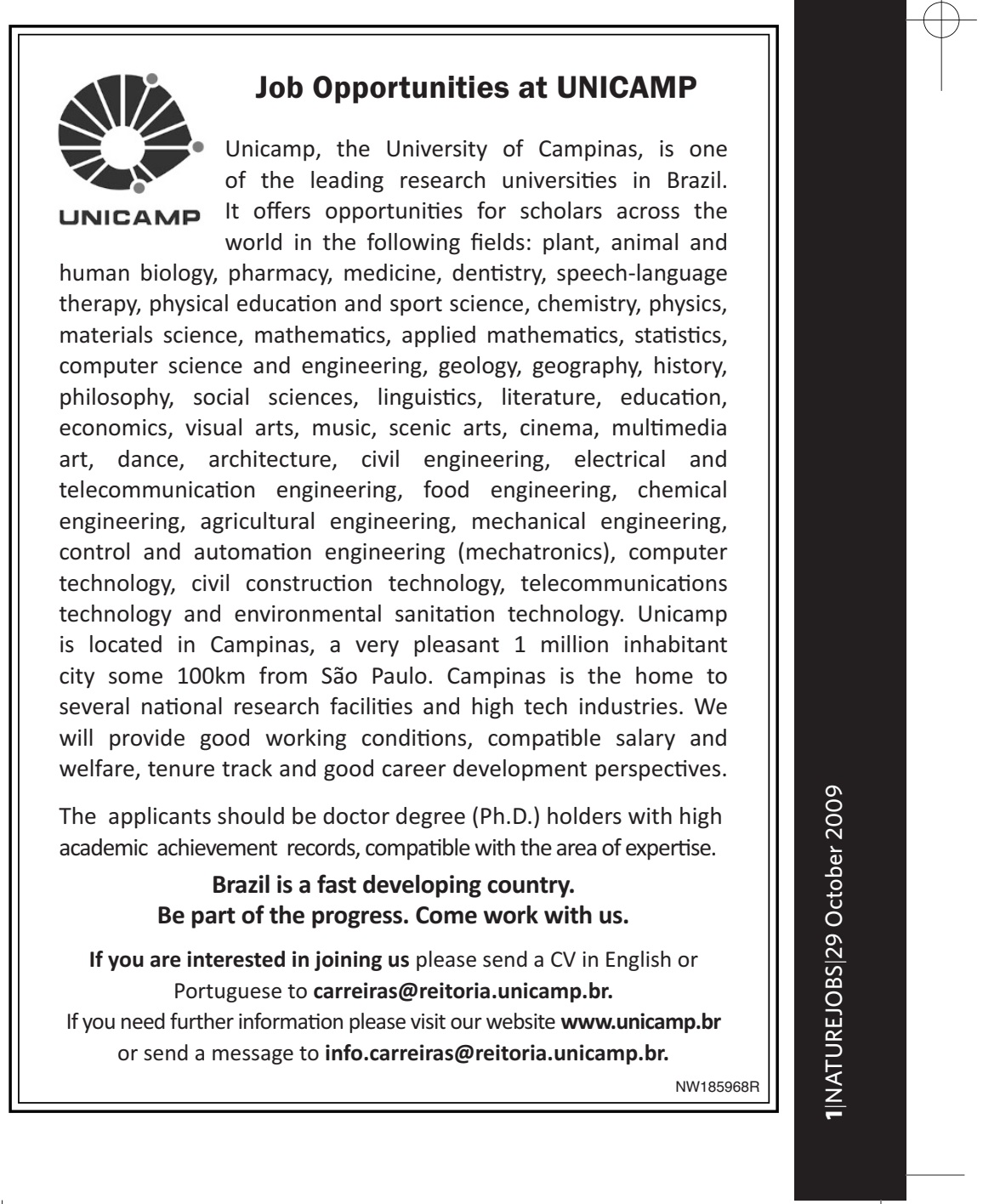




\section{PONTIFICIA UNIVERSIDAD CATÓLICA DE CHILE FI FACULTY OF BIOLOGICAL SCIENCES \\ Ph.D. PROGRAM IN BIOLOGICAL SCIENCES}

The Pontificia Universidad Católica de Chile, one of the most prestigious universities in the continent, and its Graduate Program in Biological Sciences invites talented young scientists in Latin America and the rest of the world, to apply to our Ph.D. program, which for more than 50 years has provided graduate-level training to students in Chile, the Americas and Europe. The program, composed of 63 faculty and over 200 graduate students, is divided into four streams: Cellular and Molecular Biology, Ecology, Molecular Genetics and Microbiology, and Physiology. The program provides a flexible curriculum that emphasizes interdisciplinary research in areas such as Biomedicine, Biodiversity and Global Change Developmental Biology, Plant Genomics, Systems Biology, Bioinformatics and Environmental Microbiology. Several Centers of Excellence and Interdisciplinary Science contribute to our graduate program and provide unparallel opportunities for advanced training, research internships and interaction with a broad group of scientists.

To find out more about one of Latin America's premier Ph.D. programs in biology visit www.bio.puc.cl

NW186794R

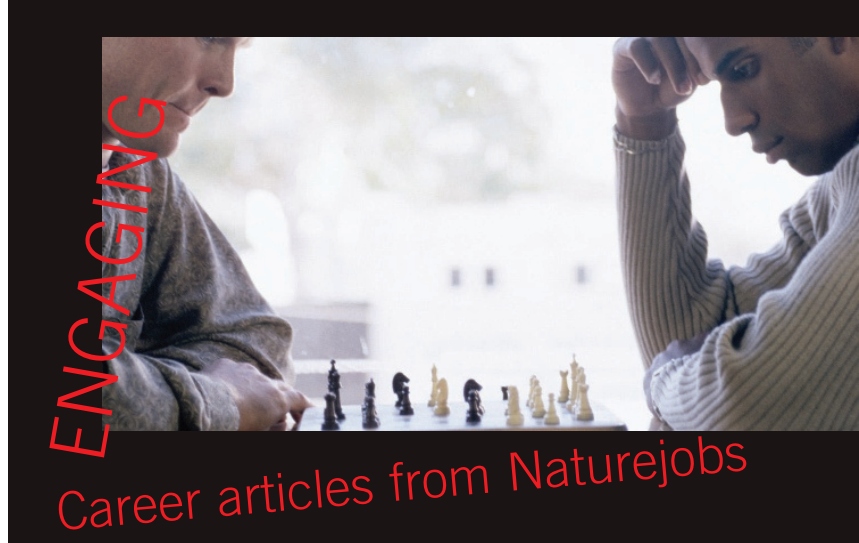

- Naturejobs Prospect: quick takes on career implications of current events

- Naturejobs Special Report: examinations of jobs issues on both sides of the bench

- Naturejobs Careers \& Recruitment: discipline-by-discipline exploration of opportunities

- Naturejobs Regions: tours of scientific hubs

- Naturejobs Movers: traffic reports that follow high-profile scientific globe-trotters and sector-hoppers

- Naturejobs Postdocs \& Students: guides to taking a step toward a permanent position

\section{Take your career beyond this world!}

\section{Would you like to be a Space Mission} Scientist? Find out more in the latest Naturejobs podcast recorded at The Source Event career fair.

Hear how Sima Adhaya landed her job as a Senior Technical Officer with Sciemus, analyzing the technical risk of space missions. She determines whether a space mission will succeed or not. She's even looked into the future of space tourism.

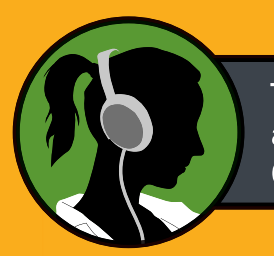

This podcast, plus many more, are available to download for free within the Career Toolkit section of naturejobs.com.

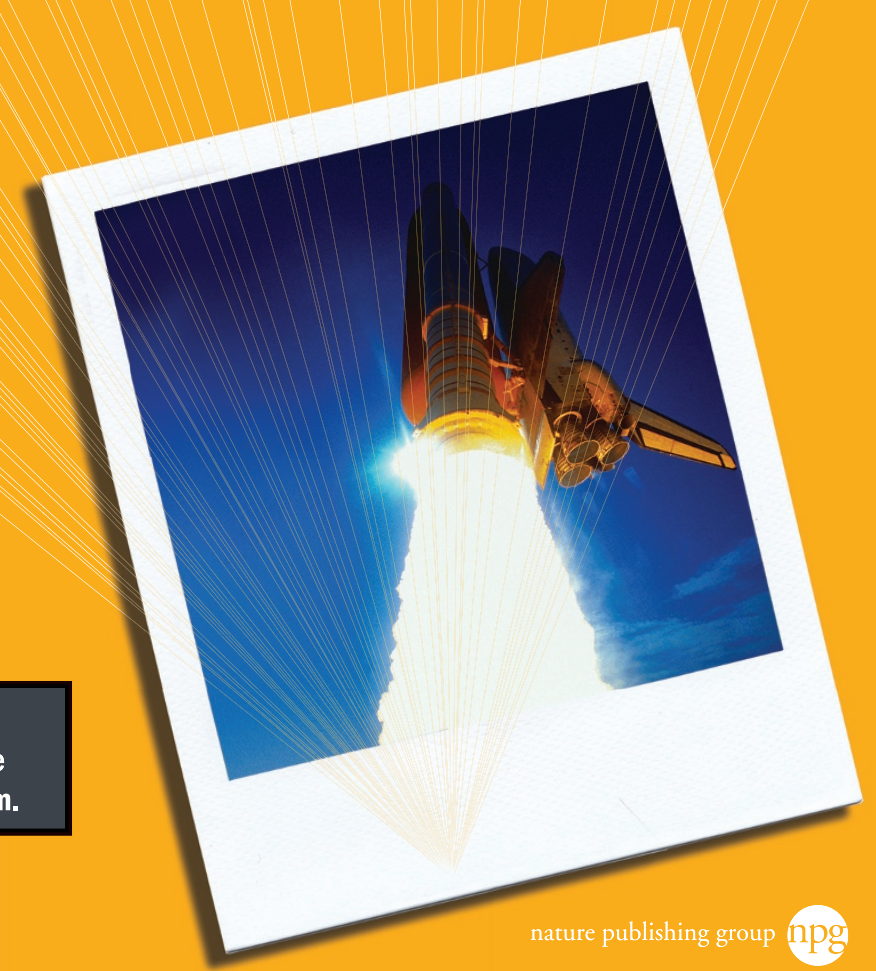




\title{
רos Andes
}

\author{
Faculty of Sciences
}

The School of Sciences of the Universidad de los Andes (Bogotá - Colombia) is a center for higher education that fosters the development of the exact and natural sciences through teaching and research. The departments offer undergraduate programs leading to degrees in Biology, Chemistry, Mathematics, Microbiology, and Physics, as well as graduate programs leading to M.Sc. degrees in Biology, Physics, Mathematics and Microbiology, and Ph.D. degrees in Biological Sciences, Physics and Mathematics. Research activities are conceived as the very core that articulate the School's Programs. The School has a highly qualified full-time faculty and numerous research centers associated with its departments.

Activities: university education and scientific research in the areas of Biological Sciences, Chemistry, Physics and Mathematics.

\section{DEPARTMENT OF BIOLOGICAL SCIENCES}

Director: Dr. Mauricio Linares Porto, Ph.D.

Email:mlinares@uniandes.edu.co

M.Sc. and Ph.D. Programs Director: Dr. Adolfo Amézquita, Ph.D.

Email: aamezqui@uniandes.edu.co

Tel: +57 (1) 339 4949, ext. 2750

http://cienciasbiologicas.uniandes.edu.co/

》 Programs: Ph.D. and M.Sc. in Biological Sciences, B.Sc. in Biology and Microbiology

》 Centers and Research Groups:

- Primatology and Ecology of Tropical Forests

- Biochemistry

- Tropical Parasitology

- Microbiology

- Ecophysiology, Behaviour and Herpetology

- Molecular Biology of Parasites

- Evolution, Population Genetics and Phylogeography

- Human Genetics

- Evolutionary Biology of Vertebrates

- Marine Molecular Biology

- Botany and Systematics

- Molecular Diagnosis and Bioinformatics

- Ecological and Food Microbiology

- Plant Physiology

- Mycology and Phytopatology

- Zoology and Animal Ecology

\section{DEPARTMENT OF CHEMISTRY}

Director: Dr. Wolfram Baumann, Ph.D.

Email:wbaumann@uniandes.edu.co

Tel: +57 (1) 339 4949, ext. 2786 - Fax +57 (1) 3324366 http://quimica.uniandes.edu.co

»Programs: B.Sc. in Chemistry

»Centers and Research Groups:

- Flavor Chemistry and Food Science

- Thermodynamics of Solutions

- Porous Materials and Applied Calorimetry

- Advanced Oxidation Processes for Environmental

Remediation

- Chemistry of the Inorganic - Organic Interface

- Group of Adsorbents and Catalysis for Environmental

Protection

- Electrochemistry and Polymer Materials

- Bioorganic Compounds Research Group

\section{DEPARTMENT OF MATHEMATICS}

Director: Dr. René Meziat, Ph.D.

Email: rmeziat@uniandes.edu.co

M.Sc. and Ph.D. Programs Director: Ahmed Ould, Ph.D.

Email: aould@uniandes.edu.co

Tel: +57 (1) $3324340-$ Fax +57 (1) 3324427

http://matematicas.uniandes.edu.co/

》 Programs: Ph.D., M.Sc. and B.Sc. in Mathematics

》Areas which are currently represented in the research activities of the faculty are:

- Logic

- Topology

- Differential Geometry

- Algebra

- Functional Analysis

- Mathematical Physics

- Optimization

- Numerical Analysis

- Stochastic Analysis

\section{DEPARTMENT OF PHYSICS}

Director: Dr. Ferney Rodríguez Dueñas, Ph.D.

Email: frodrigu@uniandes.edu.co

M.Sc. and Ph.D. Programs Director: Gabriel Tellez, Ph.D.

Email: gtellez@uniandes.edu.co

Tel: +57 (1) 3324500 - Fax +57 (1) 3324516

http://fisica.uniandes.edu.co/

》Programs: Ph.D., M.Sc. and B.Sc. in Physics

》Centers and Research Groups:

- Astronomy

- Biophysics

- High Energy Physics (or elementary particles)

- Condensed Matter Physics

- Geosciences

- Theoretical Physics

- Quantum Optics

UNIVERSIDAD DE LOS ANDES - FACULTAD DE CIENCIAS (School of Sciences)

Carrera $1 N^{\circ} 18 \mathrm{~A}$ - 10, Bogotá, Colombia (South America) | Telephone: +57 (1) 3324533 - Fax: +57 (1) 3324352 http://ciencias.uniandes.edu.co/ 